\title{
THERMAL ANALYSIS OF MULTI-WALLED CARBON NANOTUBES MATERIAL OBTAINED BY CATALYTIC PYROLYSIS OF POLYETHYLENE
}

\author{
Aleksandra Buzarovska ${ }^{1}$, Viktor Stefov ${ }^{2}$, Metodija Najdoski ${ }^{2}$, Gordana Bogoeva-Gaceva ${ }^{1}$ \\ ${ }^{1}$ Faculty of Technology and Metallurgy, Ss. Cyril and Methodius University, Rugjer Bošković 16, \\ 1000 Skopje, Republic of Macedonia \\ ${ }^{2}$ Institute of Chemistry, Faculty of Natural Sciences and Mathematics, Ss. Cyril and Methodius University, \\ P.O. Box 162, 1001 Skopje, Republic of Macedonia \\ abuzar@tmf.ukim.edu.mk
}

\begin{abstract}
Chemical recycling of non-biodegradable postconsumer polymers represents a promising route for the conversion of waste plastics into feedstock for fuel, chemicals and materials production. Recently, waste plastics have been used as low cost feedstock for carbon nanotubes growth. In this work, the thermal behavior of multi-walled carbon nanotubes material (MWCNTs) obtained by catalytic pyrolysis of waste low-density polyethylene was analyzed. Following the improved protocol, developed a few years ago for the thermal analysis of CNTs, thermogravimetric analysis of the MWCNTs material has been performed using heating rates of $2-20^{\circ} \mathrm{C}^{-\mathrm{min}^{-1}}$ and curve fitting method in an attempt to quantify the complex oxidation behavior of the material. It has been shown that competitive oxidation/combustion processes greatly influence the DTG curves and the number of fitted peaks.
\end{abstract}

Keywords: MWCNTs; thermogravimetry; oxidation/combustion

\section{ТЕРМИЧКА АНАЛИЗА НА ПОВЕК์ЕЗИДНИ ЈАГЛЕРОДНИ НАНОЦЕВЧИЊА ДОБИЕНИ СО КАТАЛИТИЧКА ПИРОЛИЗА НА ПОЛИЕТИЛЕН}

\begin{abstract}
Хемиското рециклирање на бионеразградливите отпадни полимери претставува перспективен метод за претворба на отпадната пластика во појдовна суровина за добивање горива, хемикалии и за производство на материјали. Во последниве години отпадната пластика се употребува како евтина суровина за јаглеродни наноцевчиња. Во овој труд е анализирано однесувањето на повеќеsидни јаглеродни наноцевчиња добиени со каталитичка пиролиза на отпаден полиетилен со ниска густина при нивна термичка обработка. Применета е подобрена процедура за термичка анализа на јаглеродни наноцевчиња, предложена пред неколку години. Термогравиметриската анализа на материјалот од повеќеsидните јаглеродни наноцевчиња е изведувана при брзини на загревање од 2 до $20^{\circ} \mathrm{C} \cdot \mathrm{min}^{-1}$ и со помош на методот на интерполација на добиените термогравиметриски криви е направен обид да се квантифицира комплексниот процес на оксидација/деградација на материјалот. Покажано е дека конкурентните процеси на оксидација и согорување имаат големо влијание врз диференцијално-термичките (DTG) криви и бројот на максимуми добиени со интерполација.
\end{abstract}

Клучни зборови: повеќеsидни јаглеродни наноцевчиња; термогравиметрија; оксидација/согорување

\section{INTRODUCTION}

Carbon nanotubes are a unique nanostructured material with remarkable physical, thermal, electrical, mechanical and optical properties. During the last few decades, they have become an important industrial material for the development of nanostructures, nanocomposites and nanodevices 
[1-3]. They are synthesized by arc discharge, chemical vapor deposition, laser ablation and flame pyrolysis [4], and the resulting product is usually carbonaceous material with different contents of pure nanotubes, metal catalyst particles and other carbonaceous fractions (amorphous or crystalline carbon, fullerenes, etc.). It is well known that the quality of CNTs, especially their structure, particles properties, morphology and configuration of carbon nanotube ends, primarily depend on their production procedures. Therefore, it is difficult to find CNTs with equal properties and behavior. Characterization of CNTs is based on the usage of many methods that include scanning (SEM) and transmission (TEM) electron microscopy, x-ray diffraction, FTIR and Raman spectroscopy, BET analysis, reflectance, etc. [5, 6]. Among the techniques for their characterization, thermogravimetry is of special interest for studying their purity and thermal stability and oxidation. The presence of different carbon species and impurities in the as-produced CNTs can significantly affect their thermal behavior. For instance, amorphous carbon acts as low-temperature pre-ignition sites; therefore as-prepared CNTs typically decompose at low temperature [7]. The use of various kinds of catalysts, as well as their purification process, additionally affects CNTs properties. Since their discovery in 1991, there have been numerous studies in thermal analysis of CNTs [810], but the data interpretation to date has often been subjective [11]. This is mainly due to the close proximity or even overlapping of the peaks, which gives rise to broad, featureless DTG (derivative thermogravimetry) traces [12]. Recently, some researchers have attempted to peak fit the TG data for CNTs as a tool for improving the certainty of the method [13].

In this paper, we report the results of TGanalysis of multi-walled carbon nanotube (MWCNT) material synthesized via pyrolytic degradation of polyethylene using Co-acetate as a catalyst. In recent years, the ways of upcycling polymer waste into carbon nanotubes have been widely explored [14], due to the fact that most of the thermoplastic polyolefins contain cca. $85 \%$ of carbon. In our previous publication [15], we reported on the properties of MWCNT materials obtained by upcycling waste polyethylene, studied by XRD, SEM, Raman and TGA. SEM analysis of this material has shown that the average diameter of the tubes was $80 \mathrm{~nm}$ and the length was more than one micrometer [15]. The presence of amorphous carbon in the obtained CNT-material was confirmed by FTIR, while XRD patterns indicated the presence of metallic Co- particles [15]. The purpose of this work is to further characterize the thermal behavior of the obtained MWCNTs and to attain a better understanding of the influence of heating rate on the results of TG-analysis.

\section{EXPERIMENTAL}

The MWCNTs were produced from waste polyethylene by catalytic pyrolysis according to previously published procedure [16]. Thermogravimetry (TG) of CNTs was performed in the temperature range between 30 and $900{ }^{\circ} \mathrm{C}$ under air atmosphere with heating rates of 2, 5, 10 and $20^{\circ} \mathrm{C} \mathrm{min}^{-1}$, using Pyris, a Perkin Elmer TGA analyzer. The experiments were performed in ceramic pans with around $7 \mathrm{mg}$ of MWCNT material. The residue weight was determined directly using TG runs. The experiments were performed according to the TG protocol recommended by NIST [17]. Deconvolution and curve fitting analysis used in our investigations are subroutines of the Grams/32 program [18]. DTG curves were fitted with minimum number of peaks, using Gaussian function.

\section{RESULTS AND DISCUSSION}

Thermogravimetry as a simple analytical technique is often used to evaluate the thermal stability and characterize the purity of CNT systems. In spite of its simplicity, there are many misunderstandings related to the proper choice of the optimal heating rate, as well as to the interpretation of the results for different types of CNTs and especially for unpurified CNTs. Additional problems with unpurified CNTs might arise from the fact that the mass change in the course of TG experiments in air atmosphere is typically a superposition of the mass loss due to the oxidation of carbon into gaseous carbon dioxide and the mass gain due to the oxidation of residual metal catalyst into solid oxides [17].

TG analysis of the synthesized MWCNTs was performed on unpurified material possessing a certain quantity of the remaining catalyst. EDS has shown that the average amount of $\mathrm{C}$, Co and oxygen containing species in the material (spectrum measured at three sites of MWCNTs sample) is $78.1 \%, 19.6 \%$ and $1.8 \%$, respectively, and the coefficient of variation is less than $1.4 \%$. The high content of Co (19.6 wt \%) is due to the percent of the catalyst used in the initial PE/catalyst mixture (around $20 \mathrm{wt} \%$ ) [15]. 
TG curves obtained at different heating rates are presented in Figure 1. As shown, MWCNTs are thermally stable up to around $360-400{ }^{\circ} \mathrm{C}$, and above this temperature the process of decomposition proceeds relatively fast, which corresponds well to the literature data for unpurified CNTs [5].

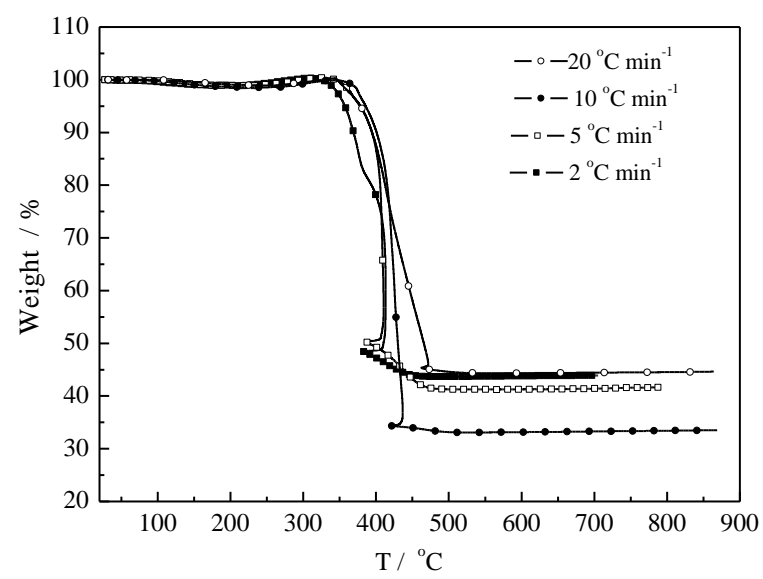

Fig. 1. TG curves of MWCNT at heating rates of $2,5,10$ and $20^{\circ} \mathrm{C} \cdot \mathrm{min}^{-1}$

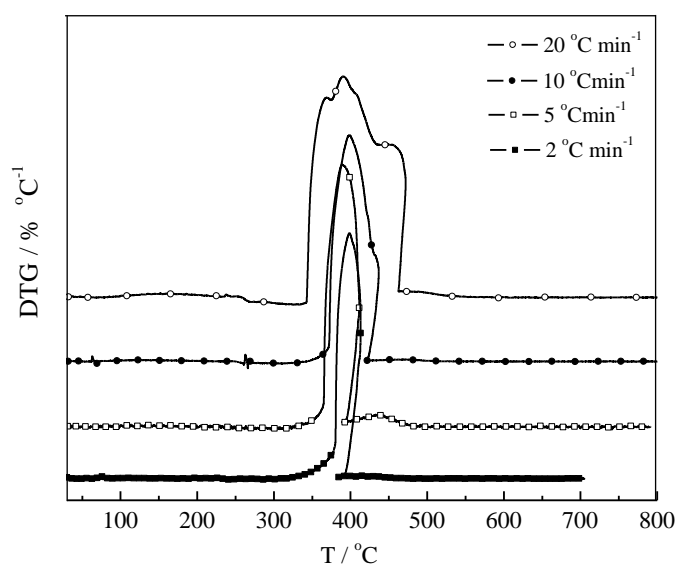

Fig. 2. DTG curves of MWCNT at different heating rates

The temperature of the maximum rate of decomposition assigned to the CNT fraction in SWCNT and MWCNT can vary from 390 to $730{ }^{\circ} \mathrm{C}$ depending on the content of metal catalysts and more reactive carbonaceous materials [19]. The onset temperature (temperature at which the oxidation process of MWCNTs starts, determined by Pyris standard software of the instrument) is influenced by the heating rate. It increases gradually from 363 and 401 to $407^{\circ} \mathrm{C}$ as the heating rates increases from 2,5 to $10^{\circ} \mathrm{C} \cdot \mathrm{min}^{-1}$, respectively; an exception is the onset temperature $\left(387^{\circ} \mathrm{C}\right)$ for the highest heating rate, and this discrepancy might be due to some specific effects observed in all TG curves. The upward swing of the TGA curve prior to the bulk mass loss is seen in all TG-traces, and might lead to some uncertainties in the determination of onset temperatures. Especially at the highest heating rate, it is difficult to reliably determine the onset temperature due to very broad transition (about $40^{\circ} \mathrm{C}$ ) (Fig. 2). This effect is most often explained by the presence of amorphous carbon and other impurities in CNTs that oxidize at lower temperatures than CNTs and also by the mass increase due to catalyst oxidation [20].

A second phenomenon, the backwards movement of the mass trace along the abscissa (at the final stages of degradation process) (Fig.1) followed by the usual forward movement, was also observed for all of the investigated heating rates. This behavior could be explained by the considerable amount of heat, released as a result of burning of unpurified MWCNTs, causing a sharp increase in temperature, followed by heat dissipation and a subsequent temperature drop [21]. Confirmation of this assumption is clearly seen from the temperature-time and weight percent-time graphs (Figs. 3a, $3 b, 3 c$ and $3 d$ ) derived from TGA curves. It is evident that the above-mentioned phenomenon is accompanied by a sudden and significant weight loss and the appearance of a spike in the temperaturetime curve.

In other words, this effect is believed to be a result of combustion, which in general is favored in unpurified systems usually containing a significant amount of metal catalyst. It has been shown that the position of each oxidation peak is strongly affected by the amounts and microstructures of the metal particles, because these particles also catalyze the oxidation of all carbon forms present in the nanotube material [22]. A similar effect was identified for MWCNTs containing lower amounts of catalyst [23], but the extent of this phenomenon was significantly reduced by reducing the amount of the initial sample (around $2 \mathrm{mg}$ ).

As seen from Figure 3, the sudden increase in temperature does not correspond with a linear TG-temperature rump and is most pronounced at the highest heating rate; it represents an unambiguous sign of combustion. To minimize misleading results obtained by TGA, the combustion should be differentiated from the oxidation process of CNTs. It should be mentioned that the combustion process is also related to weight residues.

Some of the TGA protocols for purity evaluation employed conventional $\mathrm{TG}$ performed at $5{ }^{\circ} \mathrm{C} / \mathrm{min}$ and below in order to avoid the combustion process [19]. Our investigation also supports the advantage of employing lower heating rates in TGA experiments, and especially in the analysis of unpurified CNTs. 

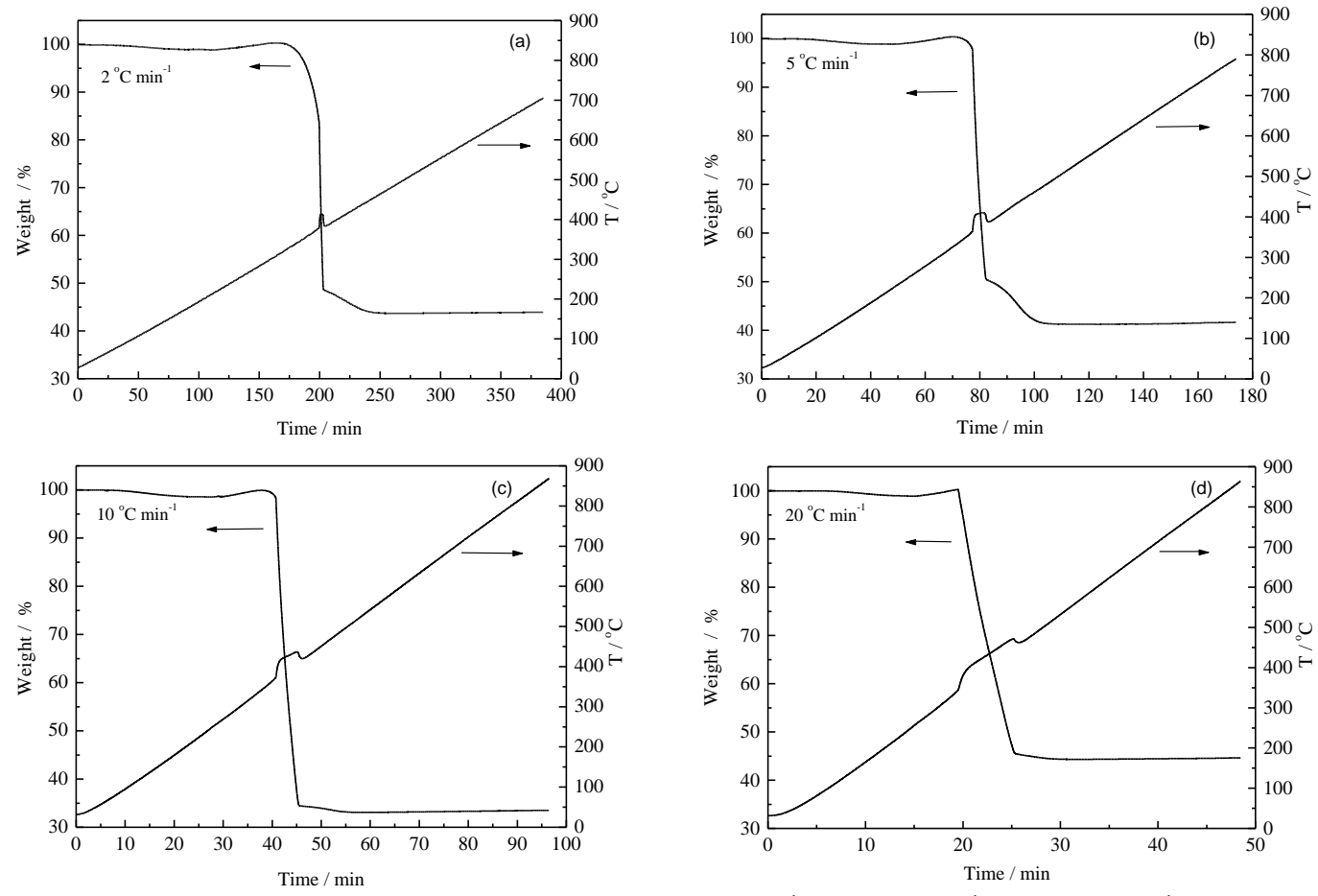

Fig. 3. Temperature-time and weight percent-time graphs at (a) $2{ }^{\circ} \mathrm{C} \cdot \mathrm{min}^{-1}$, (b) $5{ }^{\circ} \mathrm{C} \cdot \mathrm{min}^{-1}$, (c) $10^{\circ} \mathrm{C} \cdot \mathrm{min}^{-1}$ and (d) $20^{\circ} \mathrm{C} \cdot \mathrm{min}^{-1}$

The weight residues obtained at $900{ }^{\circ} \mathrm{C}$ for different heating rates are $44,42,34$ and $45 \%$ for 2, 5, 10 and $20^{\circ} \mathrm{C} \mathrm{min}^{-1}$, respectively. An influence of heating rate on weight residue in TG analysis (performed both in oxidative and in inert atmosphere) of purified MWCNTs obtained by chemical vapor deposition was reported by Vilarinho et al. [24]. In their study, the percent of weight residue increased by increasing the heating rate.

DTG curve, as a first order derivative of the thermogravimetric function, could often give more precise data related to the purity of the investigated systems than the TGA curve itself. DTG curves of the synthesized MWCNT at different heating rates are presented in Figure 2. As seen from these curves, the decomposition process of MWCNTs material in air atmosphere is represented by a complex, not a single peak, which indicates the presence of fractions with different degrees of order/crystallinity and purity, decomposing gradually and/or in parallel. It is apparent and expected that the temperatures of maximum weight loss are shifted toward higher values as the heating rate was increased from 2 to $20^{\circ} \mathrm{C} \mathrm{min}^{-1}$. Also, with the increased heating rate, the DTG peaks become broader, with more pronounced shoulders, suggesting stepwise weightloss of different sample fractions.

To obtain a more detailed picture of thermal behavior of MWCNT systems, deconvolution and curve fitting procedures were performed. Deconvolution needs great care because the math- ematically obtained curve-fitting results do not always exhibit physical validity. This was clearly demonstrated by comparing the results of curve fitting of the "synthetic" and real FTIR-bands spectrum [25], which is why the minimum number of peaks is used for curve fitting the TG data. Nevertheless, important information can be extracted from Figure 4 on which fitted DTG curves (denoted with dashed lines) are presented for various heating rates. It could be seen that at scanning rates of 2 and $5^{\circ} \mathrm{C} \min ^{-1}$ (Figs $4 \mathrm{a}$ and $4 \mathrm{~b}$ ), the best fit is obtained with two peaks, while for 10 and $20{ }^{\circ} \mathrm{C} \cdot \mathrm{min}^{-1}$, the minimum number of fitted DTG peaks are three and four, respectively (Figs. $4 \mathrm{c}$ and 4d).

The fitted DTG curves of the sample featured stepwise weight-losses (even at low heating rates), which most probably correspond to the oxidation temperature for each sample fraction. It should, however, be mentioned that there are difficulties in curve fitting because of the abrupt increase in the curves at the beginning of oxidation. The obtained Gaussian lines are overlapped, and hence the discussion about the content of the fractions of MWCNTs material associated with these lines should be considered an attempt to quantify an entangled thermal behavior.

The quantitative analysis of each fraction corresponding to its peak area was performed via curve fitting and the results of peak position, widths, heights and areas are summarized in Table 1. 

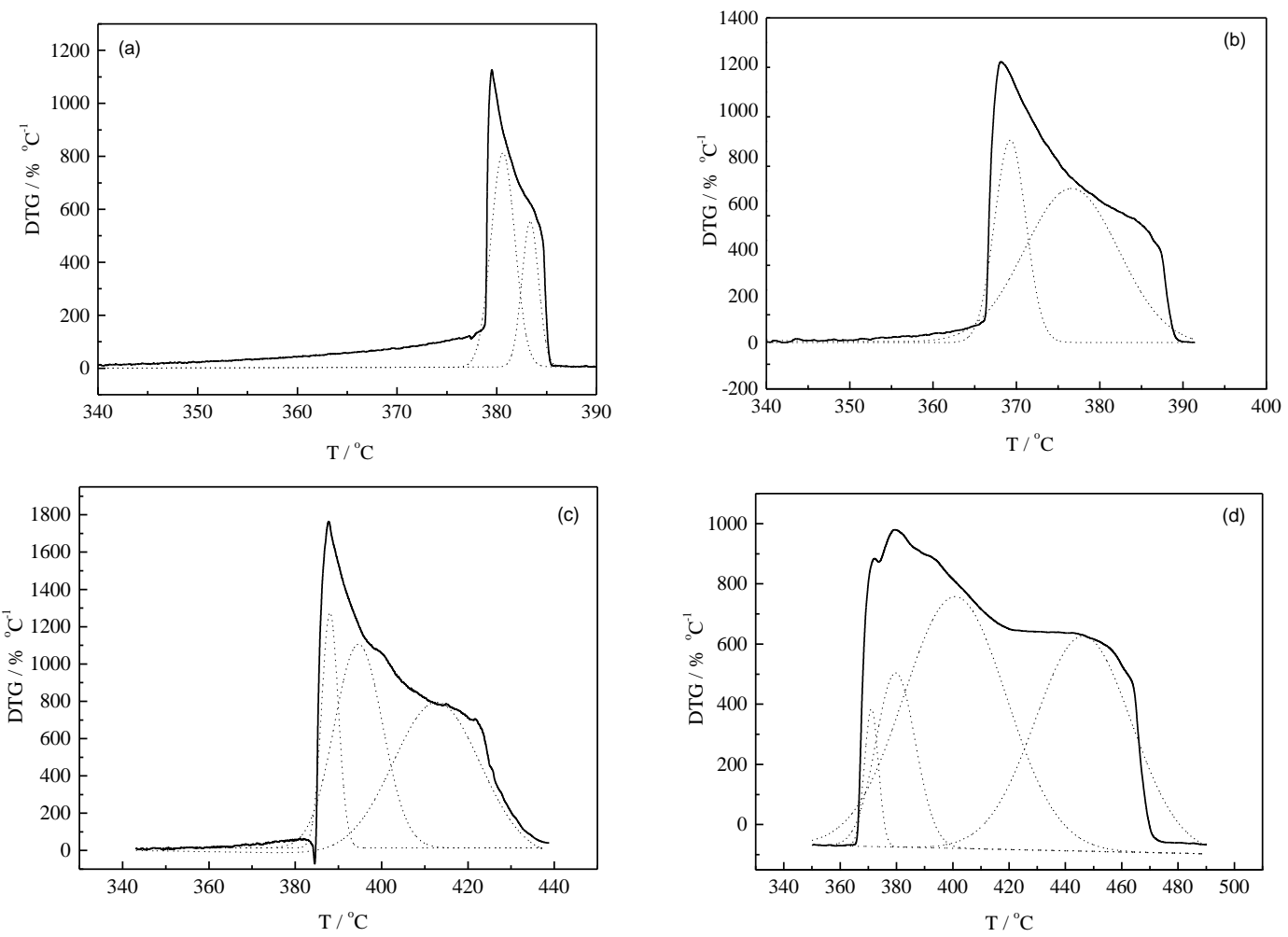

Fig. 4. DTG curves of the conventional TG's fitted with Gaussian line (a) $2{ }^{\circ} \mathrm{C} \cdot \mathrm{min}^{-1}$, (b) $5^{\circ} \mathrm{C} \cdot \mathrm{min}^{-1}$, (c) $10^{\circ} \mathrm{C} \cdot \mathrm{min}^{-1}$ and (d) $20^{\circ} \mathrm{C} \cdot \mathrm{min}^{-1}$

Table 1

DTG data of the fitted Gaussian peaks at scanning rates of 2, 5, 10 and $20^{\circ} \mathrm{Cmin}^{-1}$

\begin{tabular}{lccccc}
\hline \hline $\begin{array}{l}\text { Rate } \\
\left({ }^{\circ} \mathrm{C} \cdot \mathrm{min}^{-1}\right)\end{array}$ & $\begin{array}{c}T_{\max } \\
\left({ }^{\circ} \mathrm{C}\right)\end{array}$ & Height & $\begin{array}{c}\text { Width } \\
\left({ }^{\circ} \mathrm{C}\right)\end{array}$ & $\begin{array}{c}\text { Area } \\
(\%)\end{array}$ & St. error \\
\hline $\mathbf{2 0}$ & 370.9 & 458.4 & 5.8 & 3.4 & 0.01 \\
& 379.7 & 579.0 & 16.6 & 12.5 & 0.04 \\
& 400.9 & 836.4 & 42.7 & 46.7 & 0.08 \\
& 446.3 & 714.5 & 40.1 & 37.3 & 0.07 \\
$\mathbf{1 0}$ & 388.0 & 1108.4 & 4.53 & 13.6 & 0.003 \\
& 394.6 & 958.9 & 13.1 & 34.1 & 0.02 \\
& 419.7 & 820.9 & 23.6 & 52.3 & 0.02 \\
$\mathbf{5}$ & 369.2 & 872.8 & 4.4 & 31.8 & 0.002 \\
& 376.6 & 625.4 & 13.2 & 68.2 & 0.01 \\
$\mathbf{2}$ & 379.7 & 757.5 & 1.3 & 23.3 & 0.0005 \\
& 381.9 & 749.4 & 4.3 & 76.7 & 0.001 \\
\hline \hline
\end{tabular}

As mentioned, the number of fitted DTG peaks is dependent on the heating rate. To clarify this behavior, the DTG traces for different heating rates are plotted against time and the obtained graphs are shown in Figure 5. The combustion/oxidation process of MWCNT material is completed in time intervals from $20 \mathrm{~min}$ to $78 \mathrm{~min}$, for scanning rates of $5-20^{\circ} \mathrm{C} \mathrm{min}^{-1}$, respectively, while for the lowest scanning rate $\left(2{ }^{\circ} \mathrm{C} \cdot \mathrm{min}^{-1}\right)$ the duration of combustion/oxidation is $200 \mathrm{~min}$.

It is easy to presume that for this prolonged time (200 min), all sample fractions in MWCNT materials have enough time to complete the reactions. However, the two Gaussian lines, with very close peak maximum temperature (around $380{ }^{\circ} \mathrm{C}$ ), could not be associated with a homogeneous fraction; rather, they are associated with the portion of amorphous carbon and different CNT fractions. It is believed that the position of the peaks is also affected by the remaining catalyst distribution and other impurities in the analyzed sample [26]. For higher heating rates, the oxidation/combustion processes are probably not completely finished, and this resulted in more than two peaks in the fitted 
DTG curves, some of them being a consequence of overlapping uncompleted thermal processes. It is known that the overlapping processes also represent a typical problem when analyzing the kinetics of polymer degradation by dynamic TG [27].

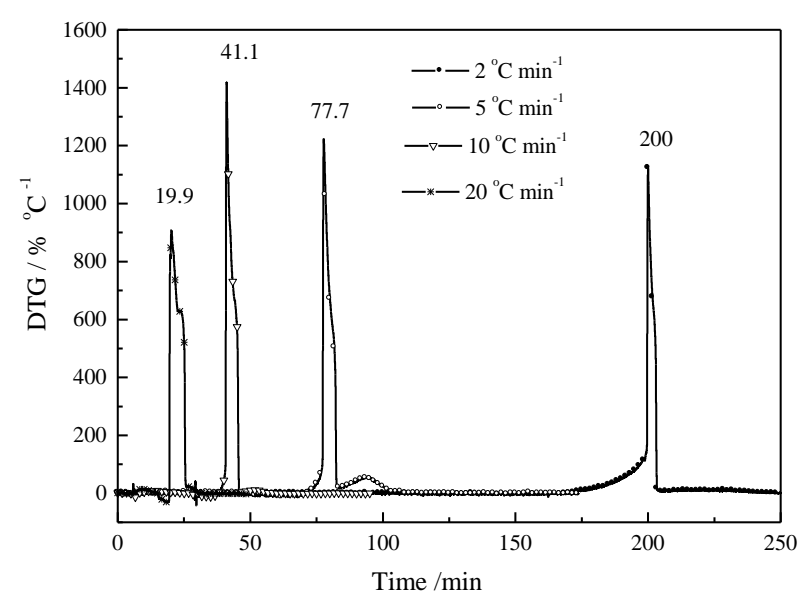

Fig. 5. DTG-time curves plotted for different heating rates

The presence of more than two fitted peaks could cause additional problems in evaluating the activation energy of thermal decomposition of MWCNTs. According to Kissinger's model [28], the activation energy could be estimated using the following equation derived from TGA data determined for different heating rates, $\beta$ :

$$
\ln \frac{\beta}{T_{p}^{2}}=\frac{E}{R T_{p}}+\ln \left[\frac{d f(\alpha)}{d \alpha}\right] \frac{A R}{E},
$$

where $T_{p}$ is the peak temperature, i.e. DTG peak temperature, $A$ is the pre-exponential factor, $E$ is the activation energy, $f(\alpha)$ is the conversion factor and $R$ is the gas constant. Plotting $\ln \left(\beta /\left(T_{p}\right)^{2}\right.$ versus $1 / T_{p}$ could lead to serious shortcomings, taking into account the number of fitted peaks for certain heating rates. From this point of view, it is unreasonable to evaluate the activation energy of decomposition for unpurified MWCNTs containing considerable amounts of remaining metal catalysts, since it is obvious that no single degradation process occurs.

If we return to fitted DTG peaks, the first one (located around $369-388^{\circ} \mathrm{C}$ ) corresponds to the initial burning of material (and taking into account its relatively low temperature, it should be ascribed to the amorphous carbon fraction), and even though it does not show any correlation with the scanning rate, the surface area under this peak is significantly increased with a decreasing heating rate (from $3.4 \%$ for $20^{\circ} \mathrm{C} \cdot \mathrm{min}^{-1}$ to $23-32 \%$ for the lowest rates). The oxidation temperatures of the remaining fractions correspond to the MWCNTs. The temperature difference between the last and first fitted peak is $2.2,7.4,31.7$ and $75^{\circ} \mathrm{C}$ for heating rates of $2,5,10$ and $20^{\circ} \mathrm{C} \mathrm{min}^{-1}$, respectively.

The amorphous carbon thin coating is generally very reactive and is often characterized as the first fraction capable of oxidizing [7]. According to data in the literature, the organization of amorphous CNT material could be different, and therefore its degradation temperatures might vary over a wide temperature range. If the amorphous fractions are organized in aggregates, then the oxidation process proceeds at a higher temperature compared to amorphous non-aggregated portions. The presence of catalytic particles in MWCNT sample is known to play a significant role in TGA [29]. Obviously, the heating rate employed in TG influences their reactivity as well, and this might have additional effects on the thermal behavior of MWCNT material and the overall data derived from TG/DTG curves. Our previous SEM investigation has shown that the unpurified MWCNT material contains approximately 20-30 wt\% amorphous carbon and approximately $30 \mathrm{wt} \%$ carbon coated particles from the catalyst [15]. The determined area of the first DTG mass loss peak for heating rates of $2^{\circ} \mathrm{Cmin}^{-1}(23.3 \%)$ and $5^{\circ} \mathrm{C} \cdot \mathrm{min}^{-1}$ $(31.8 \%)$ correlates with the amount of amorphous carbon presumed by SEM.

\section{CONCLUSION}

The line shape analysis of DTG seems to be a promising tool in attempting to quantify the complex oxidation behavior of MWCNT material and the decomposition of its fractions. It is not possible to discuss the nature of these fractions without detailed step-by-step investigation of the products of decomposition at each stage of oxidation. The results obtained in this study have shown that the preferable heating rates in TG analysis should be as low as $5{ }^{\circ} \mathrm{C} \mathrm{min}^{-1}$. At higher heating rates, the oxidation/decomposition processes could result in overlapping DTG peaks that are difficult for analysis and, as a consequence, it could deliver confusing results. The presence of metal in the sample of MWCNTs has a considerable influence on the thermal stability and the percent of weight residuals.

\section{REFERENCES}

[1] N. G. Sahoo, S. Rana, J. W. Cho, L. Li, S. H. Chan, Polymer nanocomposites based on functionalized carbon nanoptubes, Prog. Polym. Sci., 35, 837-867 (2010). 
[2] X. Wang, Z. Z. Yong, Q. W. Li, P. D. Bradford, W. Liu, D. S. Tucker, W. Cai, H.Wang, F. G. Yuan, Y. T Zhy, Ultrastrong, stiff and multifunctional carbon nanotube composites, Mater. Res. Lett., 1, 19-25 (2013).

[3] M. Moniruzzaman, K. Winey, Polymer nanocomposites containing carbon nanotubes, Macromolecules., 39, 5194-5205 (2006).

[4] J. Prasek, J. Drbohlavova, J.Chomoucka, J. Hubalek, O. Jasek, V. Adam, R. Kizek, Methods for carbon nanotubes synthesis - Review, J. Mater. Chem., 21, 1587215884 (2011).

[5] J. H. Lehman, M. Terrones, E. Mansfield, K. E. Hurst, V. Meunier, Evaluating the characteristics of multiwall carbon nanotubes, Carbon., 49, 2581-2602 (2011).

[6] D. Y. Kim, C. M. Yang, Y. S. Park, K. K. Kim, S. Y. Jeong, J. H. Han, Characterization of thin multi-walled carbon nanotubes synthesized by catalytic chemical vapor deposition, Chem. Phys. Lett., 413, 135-141 (2005).

[7] A. Lima, A. Masumeci, H-W. Liu, E. Waclawik, G. Silva, Purity evaluation and influence of carbon nanotubes on carbon nanotube/graphite thermal stability, $J$. Therm. Anal. Calorim., 97, 257-263 (2009).

[8] L. S. K. Pang, J. D. Saxby, S. P. Chatfield, Thermogravimetric analysis of carbon nanotubes and nanoparticles, J. Phys. Chem., 97, 6941-6942 (1993).

[9] S. Santangelo, G. Messina, G. Faggio, M. Lanza, A. Pistone, C. Milone, Calibration of reaction parameters for the improvement of thermal stability and crystalline quality of multiwalled carbon nanotubes, J. Mater. Sci., 45, 783-792 (2010).

[10] G. S. B. McKee, K. S. Vecchio, Thermogravimetric analysis of synthesis variation effects on CVD generated multiwalled carbon nanotubes, J.Phys.Chem. B., 110, 1179-1186 (2006).

[11] K. S. Dilip, P. K. Iyer, P. K. Giri, Diameter dependence of oxidative stability in multiwalled carbon nanotubes: role of defects and effect of vacuum annealing, J. Appl. Phys., 108, 084313 (2010).

[12] J. Yang, R. Miranda, C. Roy, Using the DTG curve fitting method to determine the apparent kinetic parameters of thermal decomposition of polymers, Poly. Deg. Stab., 73, 455-461 (2001).

[13] B. Scheibe, E. Borowiak-Palen, R. J. Kalenczuk, Oxidation and reduction of multiwalled carbon nanotubespreparation and characterization, Mater. Charact., 61, 185-191 (2010).

[14] C. Zhuo, Y. A. Levendis, Upcycling waste plastics into carbon nanomaterials: A Review, J. Appl. Polym.Sci., 13139931 (2014).

[15] V.Stefov, M. Najdoski, G. Bogoeva-Gaceva, A. Buzarovska, Properties assessment of multiwalled car- bon nanotubes. A comparative study, Synth. Met., 197, 159-167 (2014).

[16] V. G. Pol, P. Thiyagarajan, Remediating plastic waste into carbon nanotubes, J. Environ. Monit., 12, 455-459 (2010).

[17] S. Freiman, S. Hooker, K. Migler, S.Arepalli, Measurements Issues in Single-wall Carbon Nanotubes, National Institute of Standards and Technology, Special Publication, Washington, USA (2008).

[18] GRAMS/32 Spectral Notebase, Version 4.10, Galactic Industries Corporation. (1996).

[19] A. W. Masumeci, G. G. Silva, W. N. Martens, E. R. Waclawik, R. L. Frost, Thermal decomposition and electron microscopy studies of single-walled carbon nanotubes, J. Therm. Anal. Calorim., 88, 885-891 (2007).

[20] O. M. Dunens, K. J. MacKenzie, A. T. Harris, Synthesis of multiwalled carbon nanotubes on fly ash derived catalysts, Environ. Sci. Technol., 20, 7889-7894 (2009).

[21] S.Arepalli, P. Nikolaev, O. Gorelik, V. G. Hajdjiev, W. A. Holmes, B. S. Files, L. Yowell, Protocol for the characterization of single-wall carbon nanotube material quality, Carbon., 42, 1783-1791 (2004).

[22] NASA Tech Briefs (MSC-23507-1) 34 (2010). www.techbriefs.com/component/content/article/5-ntb/ tech-briefs/materials/7833

[23] V. Ambroigi, G. Gentile, C. Ducati, M. C. Oliva, C. Carfagna, Multiwalled cabon nanotubes functionalized with maleated poly(propylene) by a dry mechanochemical process, Polymer., 53, 291-299 (2012).

[24] A. M. Mahajan, A. Kingon, A. Kukovecz, Z. Konya, P. M. Vilarinho, Studies on the thermal decomposition of multiwall carbon nanotubes under different atmospheres, Mater. Lett., 90, 165-168 (2013).

[25] G. Bogoeva-Gaceva, A. Grozdanov, E. Maeder, The effect of the interphase on kinetic peculiarities in model carbon fiber/epoxy composites studied by FTIR microscopy, Polimeri., 18 (5-6), 215-221 (1997).

[26] G. B. S. McKee, C. P. Deck, K. S. Vecchio, Dimensional Control of multi-walled carbon nanotubes in floating catalysts CVD synthesis, Carbon., 47, 2085-2094 (2009).

[27] R. Artiaga, R. Cao, S. Naya, B. Gonzales-Martin, H.L. Mier, A. Garcia, Separation of overlapping processes from TGA data and verification by EGA, Journal of ASTM International, Sept. 2002, Paper ID: available online at www.astm.org

[28] H. E. Kissinger, Reaction kinetics in differential thermal analysis, Anal. Chem., 29, 1702-1706 (1957).

[29] H. Li, N. Zhao, C. He, C. Shi, X. Du, J. Li, Thermogravimetric analysis and TEM characterization of the oxidation and defect sites of carbon nanotubes synthesized by CVD of methane, Mater. Sci. Eng. A., 473, 355-359 (2008). 